\title{
Methylmalonic Aciduria, cblB Type
}

National Cancer Institute

\section{Source}

National Cancer Institute. Methylmalonic Aciduria, cblB Type. NCI Thesaurus. Code C142172.

An autosomal recessive form of methylmalonic aciduria, caused by mutation(s) in the MMAB gene, encoding cob(I)yrinic acid a,c-diamide adenosyltransferase, mitochondrial. 